\title{
Land Use Challenges in Mining Communities - The Case of Tarkwa-Nsuaem Municipality
}

\author{
Theresa Y. Baah-Ennumh", Gifty Adom-Asamoah \\ Department of Planning, Faculty of Art and Built Environment, Kwame Nkrumah University of Science and Technology, Ghana
}

Copyright $\subseteq 2019$ by authors, all rights reserved. Authors agree that this article remains permanently open access under the terms of the Creative Commons Attribution License 4.0 International License

\begin{abstract}
Mining and its related activities usually attract people to host communities. High population and intense mining activities pose numerous challenges to land use management. The study examined the planning responses to the land use challenges in mining communities in the Tarkwa-Nsuaem Municipality of Ghana. The case study research approach was used to address the research objectives. The study covered the Tarkwa township and its peripheral communities, such as Nsuta, Tamso, New Atuabo and Abonteakoon (Akoon), which were purposively selected. The paper reveals that mining in the Municipality has resulted in increased population without corresponding infrastructure and related services. Due to the intense nature of mining activities coupled with increased population, there has been strong competition over available lands which have resulted in changing land uses outside formal planning schemes, encroachments, and building in waterways and wetlands. The study recommends among others, an effective collaboration between the traditional leaders and city authorities to clearly define the mandate of each stakeholder within the urban land market. There is also a need to build institutional capacity and contextualize planning ideals as key for managing rapidly growing mining towns in emerging economies.
\end{abstract}

Keywords Land Use Planning, Mining, Environment, Planning Standards

\section{Introduction}

Mining activities are very significant, particularly in terms of the number of people employed and its economic contributions. The challenges of poverty, marginalisation and vulnerability characterize the livelihoods of the majority of individuals involved in the sector (Buxton 2013). The nature of mining activities and the land use challenges associated with it are usually not well translated into public policy and development interventions. As a result, the negative impact of mining, such as land degradation, excessive use of dangerous chemicals, air and water pollution, deforestation, poor health and safety and child labour are not systemically addressed to minimize the negative impact. Many poor people in developing countries consider the mining sector as an area of opportunity to reduce or even eradicate poverty (Avirgan et al, 2005). Many people in search of better economic prospects therefore migrate to mining communities. The high population in mine host communities however has serious adverse effects on the environment and present several land use challenges and adherence to planning standards.

\section{Literature Review}

Land use management remains a major constraint to urban growth and planning in many mining communities in Africa. This is shaped by their socio-economic and political development trajectories. The main reasons attributed to this are the continuous dependence on out-dated planning laws and regulations handed down as a colonial legacy. Another reason is the highly "unstable" urban land market which is dominated by traditional and private actors and institutions which operate largely outside the formal urban planning system. Due to the increasing urbanization in the mining communities, authorities encounter many challenges in achieving efficient and effective land use planning and management (Owusu- Ansah and Attah-Boateng, 2016). This creates challenges in the application of sound urban planning policies. Land use management and controls in mining communities have achieved very little degree of success, even in the developed economies (Mandkerlker and Payne, 2001). Studies have shown that several mining communities in Sub-Sahara Africa are confronted with uncoordinated land use management with diverse spatial implications (Ilesanmi, 2010; Boamah, 2013; Lekwot et al., 2013; Arimah and Adeagbo, 2000).

Mining remains a very significant sector in many developed and developing economies and has resulted in 
both positive (employment creation, revenue and livelihood support) (NECA, 2004; Chapin and Kaiser, 1979; Turner et al, 1995 and FAO, 1995) and negative outcomes in land use and land cover changes, notably, destruction of green areas, pollution of water and destruction of forestry resources among others (Hruschka and Echavarria 2011; Dorner et al. 2012). As a result of these and several other challenges, there are calls for policy and planning responses on a global scale to effectively address them.

\subsection{Responses to Land Use Challenges}

Responses to land use challenges have been in the form of regulations, programmes and strategies. Significant among them is zoning and land use planning which aim at ensuring that activities are organized and developed in physical spaces with due consideration for the protection of the public interest which include health, safety, convenience, efficiency, energy conservation, environmental quality, social equity, social choice and amenity (Nnah et. al., 2007). Land use planning therefore has become an important component of urban land management, where the sustainability of mining areas is influenced directly by land use controls. (Owei et al, 2009). As such, effective land use planning is necessary in mining communities to ensure harmony, reduce land use conflicts and promote environmental quality.

There are many regulations, statutes and planning responses in many African countries to ensure efficient land management and planning. However, these interventions have been less successful. Cities in Sub-Sahara Africa are still characterized by clashes; uncontrolled and uncoordinated land management which are further exacerbated by urban expansion and increased demand with far-reaching spatial and socio-economic implications. These responses have further been ineffective and slow to address the challenges. Whereas numerous literature exists on these issues, a critical review of how planning policies, laws and regulations respond to some of the land use challenges in mining communities have received very little consideration at the local level. Lands in the Municipality are predominantly owned by traditional authorities. According to the Lands Commission in the municipality, there are three major forms of land ownership within the Tarkwa-Nsuaem Municipality and these are Stool Lands, State Lands and Private/ Family Lands. In terms of the proportion of the various ownership type within the municipality, the stool lands record a proportion of about $75 \%$, state lands $24 \%$ and family lands taking 1\% (Municipal Lands Commission, 2015). Forms of holdings within the Municipality include common grazing rights, private residential and agricultural holdings, and state ownership of forest reserves. The right to sell and lease land for developmental activities is in the hands of the chiefs and people.
The mode of land acquisition by large-scale mining companies and licensed small-scale groups is mainly the concession type. These groups however sometimes face certain problems such as conflicts with the indigenes over boundaries and compensations. The illegal mining groups (galamsey) however operate wherever they can have access to gold without the required processes of land acquisition. Land is increasingly becoming scarce in mining areas due to the growing intensity of both licensed large and small-scale mining as well as that of illegal mining (galamsey) activities. Mining activities have been widely documented to result in the destruction of lands and environment (Agbesinyale, 2003; Hilson, 2002). The high population and mineral extraction, as well as its related activities, pose numerous challenges to land use and the enforcement of planning laws and related regulatory frameworks. One of the main purposes of land use and spatial planning is the elimination or reduction of conflicts among land users particularly those that are caused by incompatible land uses. The planner's primary tool for such conflict resolution is zoning. Urbanization presents challenges for land-use planning and decision-making. Urban mining communities have many land use and spatial planning challenges, such as competing land use needs between mining and conservation. This presents several challenges to planning authorities in such communities.

Almost all land use and management challenges resulting from mining activities have been found in earlier studies; some of which have been outlined above (with specific reference to Akabzaa and Darimani, 2001). These studies clearly point out that there are weak development mechanisms in mining communities (Tsikata, 1997). Land is exposed to unapproved socio-economic activities resulting in pressure on infrastructural facilities (Antwi-Boasiako, 2003); and there are conflicting land uses and risks of environmental hazards (Amegbey et al., 1997; Aryee et al., 2003; Opoku-Ware and Kutor, 2015). There is however very little attention in the mining literature on how planning laws and regulations have responded to these land use challenges. This gap in literature can undermine the implementation of targeted interventions to improve upon land use management in mining communities. This paper, therefore, examines the planning responses to land use challenges in mining communities in Ghana, taking the Tarkwa-Nsuaem Municipality as a case study. The study further explores the implications of land use practices on the environment and identifies key stakeholders and the dynamics of their stake in land use in relation to planning laws and regulations.

\section{Methodology}

\subsection{Study Setting}

Gold mining has taken place in Tarkwa and its 
surrounding communities for centuries. The Wassa indigenes of Apinto were mining gold before Europeans from Portugal and Britain arrived between 1453 and 1622 . (GSS, 2014). The geological formations in the municipality are the mineral-laden Tarkwaian and Birimian formations.

Five urban settlements namely Tarkwa, Nsuta, Tamso,
New Atuabo and Abonteakoon (Figure 1) were purposively selected for the study. The selection of the five urban communities was influenced by their population and the intensity of mining activities. These areas also experience rapid land conversions which are associated with competing land demand and land use conflicts and challenges in the Municipality.

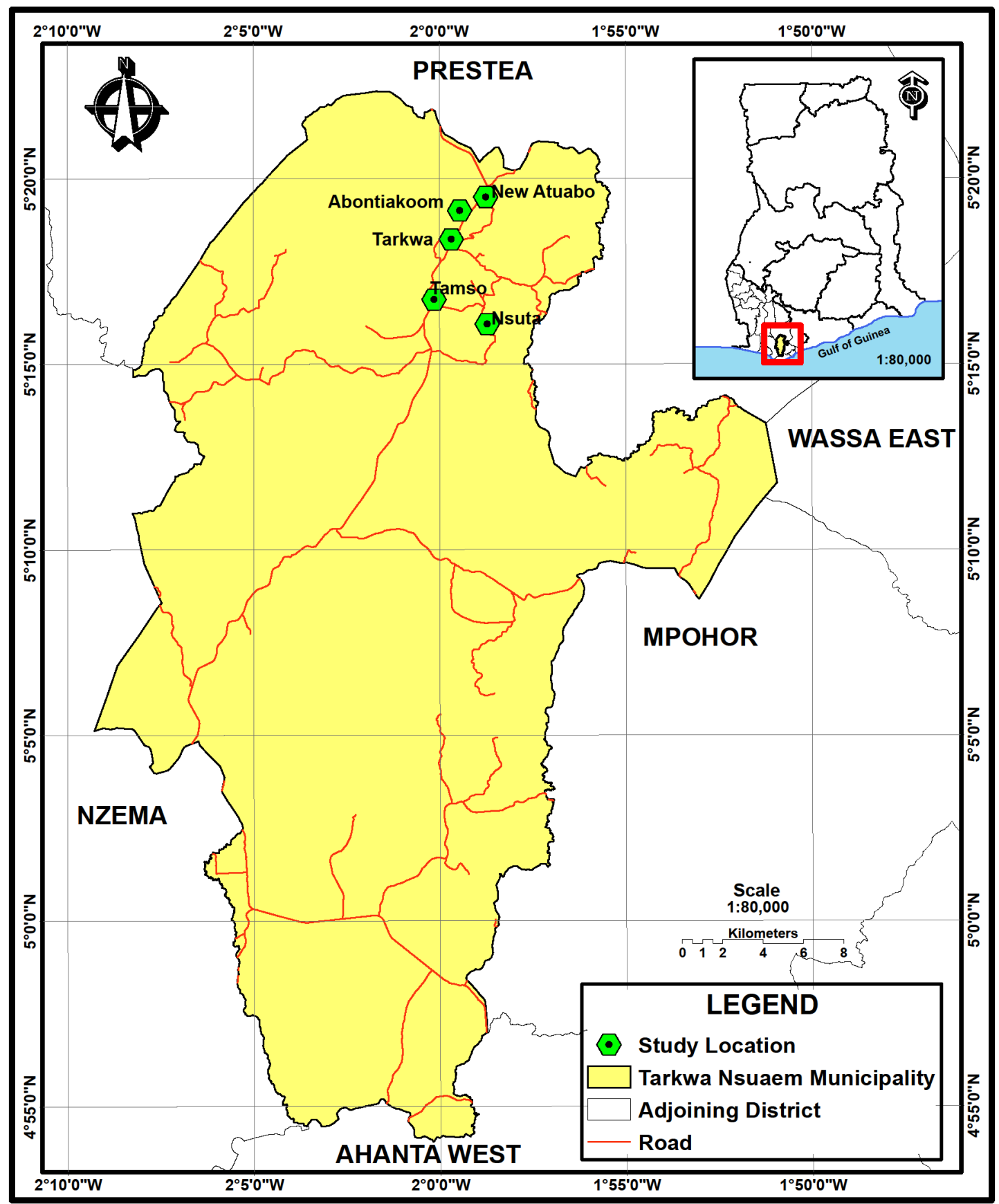

Source: Adapted from the Ghana Statistical Service, 2014.

Figure 1. Selected Study communities in the Tarkwa Nsuaem Municipality 


\subsection{Design and Samplings}

The case study research approach was used to address the research objectives.

Secondary data was obtained from documents such as; Mineral and Mining Act, 2003 (Act 706), the Local Government Act, 1992 (Act 462), Land Use and Spatial Development Act 2016, Act 925, and the Local Governance Act, 2016 (Act, 936). These documents were reviewed to better understand the provisions made in them regarding efficient land use management, planning and control and the responsible institutions for ensuring effective implementation of the regulations.

Qualitative methods were used for data collection from multiple sources of evidence. These involved institutional consultations and review of government documents on urban development, governance and land use planning and management in the Tarkwa Nsuaem Municipality. The relevant institutions covered in the study were purposively sampled because of their roles in the formulation or implementation of policies, plans and programmes that influence land use management and control in the Municipality. The institutions were the Tarkwa Nsuaem Municipal Assembly (TNMA) including the Municipal Physical Planning Department, and the Municipal Lands and Mineral Commissions. The heads of these institutions were the units of analysis for the study.

\subsection{Data Collection Tools and Process}

Interview schedules, interview guides and observational checklists were prepared and used to elicit the required responses from individuals and heads of relevant institutions (Tarkwa Nsuaem Municipal Assembly (TNMA), Municipal Physical Planning Department, and Lands Department of the Municipal Assembly). To have a better understanding of the phenomenon, five Assembly members from the study communities, traditional authorities, residents and developers were interviewed.

Direct personal interviews were used to gather relevant data from the heads of the selected institutions. Data was gathered on the nature of land uses, the land use challenges in the Municipality and the planning responses to address these challenges over the years as well as the difficulties encountered in their executions. Observational checklists were prepared to guide direct observations. The checklist covered issues on the land uses and challenges in land uses in the study communities. The data collection period was from February 2016 to July 2016 covered both the rainy and dry season periods where flooded areas and the effect of flooding on residents were observed (Fig...). Various phenomena in land use in the study communities were also observed. Owing to the use of the case study design, ten purposively sampled commercial drivers, twenty traders and buyers from both the main market and the workers' markets.

Households on the encroached lands were selected through convenience sampling, this means that those who were encountered at the time of the interview were used to understand the issues under consideration. Focus Group Discussions (FDGs) were held to have a better understanding of the issues raised by the respondents, particularly on the land use challenges and the planning responses to the challenges. The average number of participants of the FGDs was ten. The number of participants selected for the focus group discussions was based on the work of Manoranjitham and Jacob (2007) who argued that the optimal number of participants for a focus group discussion should range between eight and ten. FGDs were held for members of the communities.

\section{Findings and Discussions}

Mining activities have exacerbated the land use issues in the Municipality. As such, developers find means of acquiring "suitable" lands for their activities outside the formal planning schemes of municipal authorities. Though challenges are found in several other mining communities, the challenges in these mining towns remain intense. The land use challenges revealed by the study include encroachments on state lands, building in wetlands, general non-conformity to approved planning schemes and standards.

\subsection{Encroachment on State Lands}

The Tarkwa-Nsuaem Municipality has witnessed influx of people from other parts of the country because of its mineral endowment and consequent mining activities. According to the Ghana Statistical Service (2014), the Municipality had a total population of 90,477 for the year 2010 and a population growth rate of 3.0.

The increasing population with its attendant socio-economic activities in Tarkwa and its periphery urban communities has been a major cause of the challenges associated with land use. This according to Clark (1994) is a phenomenon experienced mostly in urbanising mining communities where access to and management of land becomes a major challenge.

The Municipality has a total land area of 978.26 sq. km, where approximately $75 \%$ of the lands are owned by the traditional authorities; i.e. customary lands. This is in tandem with Kasanga's (2008) findings where he indicated that over $90 \%$ of the total land area of Ghana is under the control of the traditional landholding institutions, thus, making the sector the dominant actor in the supply chain of the land market. This presents several challenges regarding land ownership, interests and rights in land, power relations and participation.

The study communities cover approximately 20\% (195.652 sq. km.) of the total land area of the Municipality. Interviews with the Municipal Physical Planning 
Department and observations showed that about $75 \%$ of the places zoned by the Department for specific uses have been converted to other uses outside the planning scheme. This presents a major challenge for authorities in controlling and managing lands in the Municipality. For instance, it was revealed that areas zoned as education and public open spaces in Tarkwa have been developed into residential areas. Interviews with 'encroachers' revealed that these areas were encroached upon because mining activities had created mine pits in and around their communities making it difficult to reside there. As a result, they resorted to settling or developing the areas they deemed convenient, so long as they 'legally' obtained the lands from the traditional authorities. Similar instances were also observed in New Atuabo, a resettled community which originally had a well-planned scheme. In these instances, the houses have been built along the shoulders of the roads which have blocked pedestrian walkway. A lot of structural alterations have also taken place with most of the buildings in the community. UNECA (2004) indicates that despite attempts to liberalise political space, the struggle for land is a major factor fuelling the instability of changing land uses. Mining activities had therefore played a role in leaving residents with seemingly no option than to settle in areas devoid of pits and environmentally degraded areas. This confirms similar findings by Ocansey (2013) in Kyebi in the Eastern Region of Ghana, who revealed that agricultural lands are destroyed by mining activities and so affected victims abandon such lands and resettle or encroach upon nearby 'convenient' lands for residential and farming purposes.

Similarly, another area that clearly showed non-conformity to planning standards as a result of the pulling effect of mining is the area around the railway station which has been turned into a residential area for squatters. Wooden structures with cement floors have been erected on and around the railway lines. These are developed informally. Ojigi (2012), observed that informal settlements have serious aesthetic and functional effects on the landscape and sustainable development of a city. Squatters develop outside the formal planning arrangements in their bid to survive in urban areas, primarily as a result of competition and destruction of lands by mining activities in mining communities. Issues of informality are manifested at various levels of land management system; acquisition, land delivery process, development and land titling (Gondo, 2009). The resultant effects of such deficiencies are the proliferation of developments in unapproved areas and unprecedented rise of legal disputes on land management.

Abonteakoon (which was a planned settlement where the mining company, Goldfields Ghana Limited had houses for their staff) was observed to be congested due to non-conformity to planning standards. By virtue of its location, any attempt to extend boundaries of the community will mean developing in the concession of
Goldfields Ghana Limited. Some residents have consequently encroached on railway lands while others have built houses in areas zoned out for roads. The community is frequently flooded leading to the development of cracks in buildings and consequent collapse. According to the Assembly man and some community members interviewed, water from underground seep into houses and this is believed to be caused by the activities of Goldfields after closure of the underground mine. Majority of the people who have not adhered to the planning standards see their use of a particular piece of land as a way of surviving in the urban communities of the Municipality. This is evident in what one of the respondents said "Most of their lands have been taken over by mining activities and they can only survive on where they are since they have no alternative place."

In an attempt to respond to the challenges of encroachment on state lands, the Municipal Assembly issued a disclaimer and consequently refused to give permit or endorse documents on land in such areas. Meanwhile, section 118(1) of the Land Use and Spatial Development Act 2016, Act 925 clearly states that the District Assembly may issue an enforcement notice demanding the immediate stoppage of the execution of a development or of works carried out contrary to the terms of an approved development plan. Section 119 (1a and b) further gives the Municipal Assembly the authority to prohibit, abate, remove, pull down or alter a physical development which does not conform to the approved development plan. Clearly, the Municipal Assembly's response to the challenge is not in line with what the Act mandates it to do. It is not clear how the issuance of permit could address the problem of encroachment. Obviously, instead of using the law to address the problem as mandated by the Land Use and Spatial Development Act 2016, Act 925, the Municipal Assembly found it convenient to wash its hands off the problem. The response has not solved the problem of illegal occupation of these areas. This brings to question the Municipal Assembly's role of being in charge of development controls and law enforcement. The major challenge confronting the Municipal authorities in enforcing the planning law has been "who has the right to give out lands and determine the use of it". Encroachers deem it legal to use the land for any purpose so long as they legally acquire it from the custodians of the land; traditional leaders. Others also think that they have the right to use what belongs to the state as citizens since they cannot afford a plot of land which costs between five to eight thousand Ghana Cedis ( $\mathrm{GH} \phi 5,000.00-8,000.00)$ in the study communities. This has made the management and control of the use of lands in the study communities a very challenging task for municipal authorities. This is therefore a clear indication that it is sometimes difficult for the planning authorities to ensure the enforcement of planning laws and therefore resort to denial of permits and issuance of disclaimers which do not help to address the challenges 
associated with non-adherence to planning laws. This situation has resulted in the chaotic state of land use activities in the study communities.

\subsection{Intense Congestion at the Central Business District and Inadequate Parking Spaces}

Mining activities put a lot of pressure on the land and interfere with other activities. Mining activities are revealed to be a major cause of urban sprawl (Akabzaa and Darimani, 2001; Agbesinyale, 2003; Hilson, 2002; Hilson and Potter, 2005). Commercial activities spring up to take advantage of and cater for the commercial needs of miners and residents; the youth particularly, move from other places to settle and engage in the mining activities, earn a living and support their families within and outside these communities. Urban sprawl, a potential manifestation of development, has its negative impacts in mining regions. This phenomenon often results in congestion and exert enormous pressure on existing facilities in such mining communities, where infrastructural provisions do not meet the increasing population. Central Business Districts (CBDs) of cities are areas of intense social and economic interactions and functioning (Amoako et al., 2014), receiving huge public and private investments as well as places of intense population flow in the urban environment (Yaguang, 2011). As a result, the physical expanse, land uses and functions of CBDs are in constant change to reflect the level of interactions, investments, changes in urban economies and patterns of growth. According to Olayiwola et al. (2014), urban population growth and urbanization are major factors influencing decisions with regard to CBD development activities worldwide. Traffic congestion is a major challenge in the management of CBDs. Uncoordinated and uncontrolled land use changes have resulted in congestion at the city center, resulting in high levels of insecurity. Manville and Shoup (2005) note that parking spaces are noticed most when absent, and this is so partly because most cities require parking spaces almost everywhere.

It was observed that due to the increasing population in the study communities as a result of the mining activities have led to intense congestion in the Central Business District (CBD) of Tarkwa. It was also observed that there was limited land for expansion within the centre of the city. The CBD has been taken over by both commercial and transport activities, resulting in high congestion. This has also created vehicular traffic for both north and south bound vehicles. There are usually long queues of vehicles for both the north and south bound vehicles. This increases the travel time of passengers. Commuters from Kumasi indicated that they sometimes spend more than one hour in traffic between Abonteakoon and the lorry terminal which is a distance of about $3 \mathrm{~km}$ with a travel time of about 6 minutes. This situation worsens during the morning and evening peak times. Commuters from the Northern part however indicated that the traffic congestion is usually bad in the mornings and one could spend between 30 minutes to 60 minutes in traffic between UMAT and the CBD which is a distance of about $1 \mathrm{~km}$ with a travel time of about 3 minutes when there is free flow of traffic.

It was observed that a piece of land near the bus terminal which had not been zoned for a market, has been turned into a market centre. The CBD is therefore congested with a bus terminal, market and supermarkets (All Needs, Joko, Ransbet, Benbetty and Topline super markets) as well as banks and other businesses, generating noise and air pollution and increasing open solid and liquid waste. Furthermore, the location of the main highway linking the town to other parts of the municipality, region and beyond, the presence of the railway station and the concentration of mining companies and their staff residence along the same route, have all contributed to the congestion at the CBD. These have come up as a result of the economic potential of mining activities in the communities.
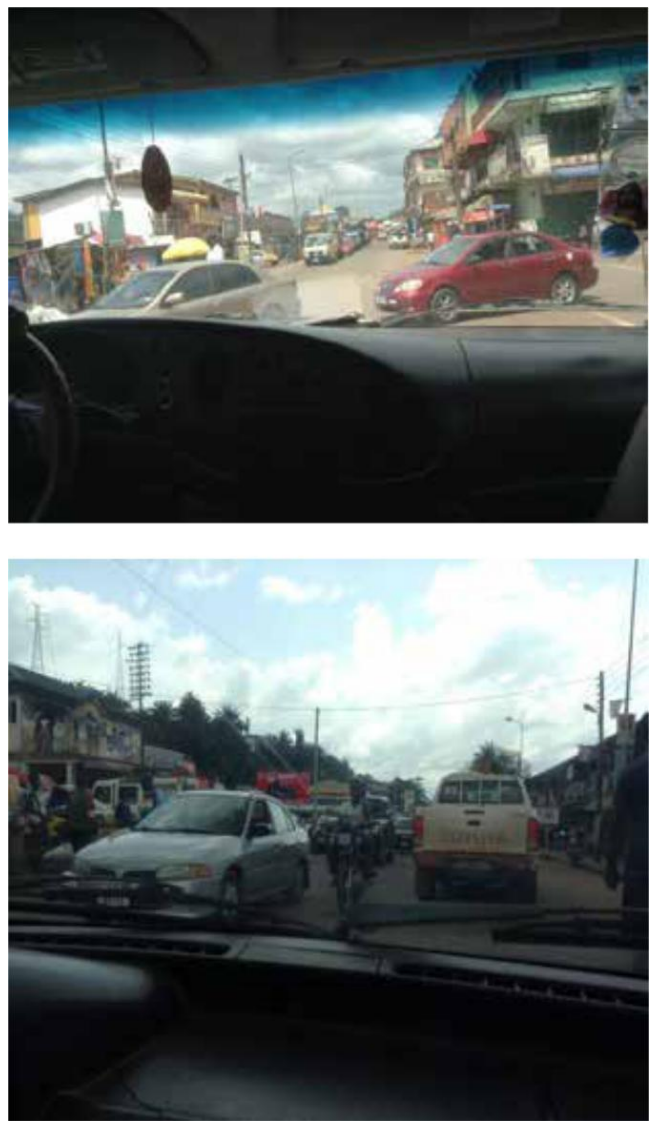

Source: Field Survey, June 2016

Figure 2. Congestion at the CBD of Tarkwa

Attempts by planning authorities and related agencies to address the congestion problem have however only focused on managing the vehicular traffic in the CBD to the neglect of the other land use and management challenges created by the commercial activities. There are however limited parking spaces in the CBD. This has 
escalated the congestion problem as shown in Figure 2. The Municipal Assembly has created parking facilities, which comprise of both on -street and off-street parking spaces. The on- street parking spaces are found on the shoulders of the North Tarkwa highway in front of the All Needs Super market, the Post Office Loop on the Bank Street, Stadium Avenue, Market Circle By-pass and on the Kedadwen road. The parking slots however range between five and ten. The portions of the roads and some streets at the market circle area in the Layout suburb have been converted to the on-street parking spaces.

Even though the creation of the parking spaces is seen as an attempt to address the problem of vehicular congestion in the $\mathrm{CBD}$, some respondents believe that it has rather exacerbated the vehicular congestion menace, especially, between Abonteakon and the CBD which also has effects on the vehicular congestion on the Bank Street between Ghana Commercial Bank junction to the main Takoradi-Bogoso road. Planning authorities however disagree with this assertion. They are of the view that the congestion problem had always been at the CBD, because of the influx of people in the city. They assert that their intervention has rather helped ease the problem. Municipal authorities further argue that the intervention has helped to reduce parking in unauthorized spaces which used to compound the problem. City authorities have further introduced sanctions against offenders. For instance, vehicles that are parked in unauthorized spaces are clamped and this attracts a fine of $\mathrm{GH} \phi 60.00$ for the first day and GH $\not 150.00$ per day for subsequent days. Though these attempts are not aimed directly at responding to mining issues, we argue that these are very important in addressing the land use and management challenges created indirectly by the mining activities in the communities. These interventions have however been slow and inadequate to address the increasing congestion and land use challenges in the CBD in any significant way. This could be attributed to the fact that not much attention has been given to the planning standards in the management of the CBDs. It was revealed for instance, that there was no Traffic Impact Assessment study (TIA) to ascertain the number of parking spaces required so as to ensure harmony in land use in the CBD. TIA studies as part of the zoning guidelines and planning standards, are pre-requisite for city authorities to effectively determine the number of spaces needed to ease vehicular congestion in cities and also ensure efficient land use management (Ministry of Environment Science and Technology, 2011). Given the general framework and prevailing knowledge, the choice of location of any activity is normally a rational decision made after an assessment of the relative advantages of various locations for the performance of the activities in question. The importance of land use decisions in any urban area tends to locate activities in places best suited for them. This however does not appear to be the case in the study communities.
Interviews with the Municipal Assembly revealed that they had further trained guards who supervise the traffic flow to the bus terminals and prevent hawking on and along the road as a means of easing the congestion situation. They also indicated that to solve the problem of congestion at the CBD, a new bus terminal has been constructed for the northern bound vehicles in New Atuabo. It was revealed that this initiative should have actually been executed about four years ago but the drivers and passengers returned to the old bus terminal at the CBD because the new place lacked basic facilities such as offices, wash rooms and parking spaces that are available at the CBD. Another reason attributed to the failure of the initial attempts to address the problem was limited participation and poor communication of the need for the location of part of the bus terminal to New Atuabo. The Municipal Assembly however has completed the New Atuabo Bus Terminal with the required facilities and will move the northern bound station to the place in the very near future (the specific time could however not be given).

Another area of congestion at the CBD was observed to be the market near the bus terminal which is popularly known as the workers' market or 'nmesiafoguom' (women's market). According to some of the market women interviewed, they had been selling at the market since it started over thirty years ago. It was identified that the market started as a very small market where people from within the municipality and beyond transported foodstuff by train and sold them near the railway station. Both fresh and smoked fish from Agona Nkwanta, Axim, Sekondi -Takoradi and other coastal towns in the Western region were also sold there. The mine workers find it convenient to shop there because it was relatively closer to where they live and work. This has developed into a market over the years in spite of the fact that the place has not been demarcated for such a purpose. The existence of the workers' market has met a lot of resistance from traders at the main market who believe that it is the cause of low patronage at the main market. It was revealed that an attempt by the Municipal Assembly to improve conditions at the market met fierce resistance from the traders at the main market. This left the Assembly in a dilemma, which usually face planning authorities in responding to critical issues.

Due to its proximity to the bus terminal both vehicles and human beings fight over the available space in that limited geographical unit. Traders and buyers share the same space with buses and other vehicles at the market. Traders are constantly forced to run away with their wares from these vehicles since they sometimes run over their displayed items. This situation renders both traders and buyers vulnerable and are left in secured. The Municipal Assembly however collect market tolls in spite of the fact that it is not in the planning scheme and therefore not a planned market site. The Assembly justifies this situation by the fact that they have provided a sanitation facility 
(skip container) and also help clean the place and dispose the refuse generated at the market. This situation is a clear indication of the dilemma of the Municipal Assembly when it comes to the issue of enforcing compliance and adherence to the planning laws and standards and implementation of the planning scheme. Failure to ensure that planning standards and regulations are adhered to have contributed to the land use challenges in Tarkwa and its periphery urban communities.

Despite the mandate given to the Assembly by the repealed Local Government Act of 1993, (Act 462) and Local Governance Act, 2016 (Act, 936) to be the regulatory and (physical) planning body of its area of jurisdiction, city authorities are unable to ensure compliance and adherence to the planning laws and standards and implementation of (land use) planning schemes. Failure to ensure that planning standards and regulations are adhered to have contributed to the land use challenges in Tarkwa and its periphery urban communities.

The study reveals that the mining activities in the Municipality particulalrly, Tarkwa has resulted in congestion and land use changes and associated challenges where areas have been used for commercial purposes outside the formal planning scheme of city authorities, especially in the CBD of Tarkwa. City authorities' responses to addressing the challenge of congestion, land use conflicts and mismanagement have sometimes been indecisive and slow with little stakeholder consultation and education.

\subsection{Building in Waterways/Wetlands}

Mining activities result in land use and land cover changes, notably, destruction of green areas, pollution of water, and destruction of lands, among others (Hruschka and Echavarria 2011; Dorner et al. 2012). Such activities when not properly regulated and carried out result in the creation of mine pits which are often abandoned, and pose threats to human beings and the environment. Mining is noted to be a major cause of (degraded) wetlands. Such lands are often deemed not suitable for physical development activities (commercial, residential, etc.) but are mostly cheaper to developers in such areas and are developed as residential areas.

It was observed that, the building of residential facilities and other physical developments in water ways and wetlands were rampant in the study areas. A typical case is the building of houses in the water way and basin of the Kawere River. Interestingly, these areas have not been earmarked for physical development activities by city authorities, because of the risks and dangers associated with building in such areas. Developers thus did not adhere to the building regulations of city authorities which presents a serious consequence for land use and management patterns. It was however identified that, due to the increasing population and competition over land, land values were high, where a plot of land in the study areas on the average costs between five to eight thousand Ghana Cedis (GH $\notin 5,000.00-8,000.00)$. Lands in the wetland areas were cheaper compared to the average plot of land sold in the area. A respondent indicated that he bought the land as far back as the year 2000 at a cost of GH $\phi$ 200.00 from the chief of the area however currently a plot of land in the same area costs between GH $\$ 3000.00-5000.00$.

Lands, as earlier indicated, are destroyed and so not easily accessible/available in such areas. Developers therefore resort to building in unapproved areas where they use laterite and mine waste stones to fill up the place.

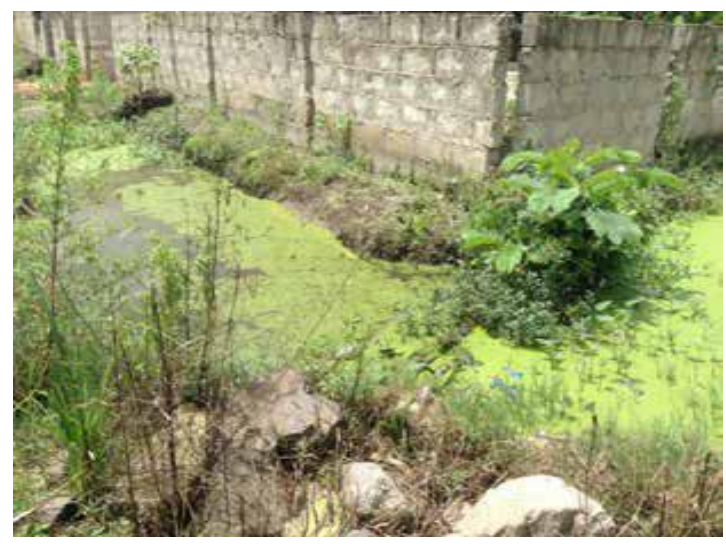

Source; Field Survey, June 2016

Figure 3. Building in a Wetland

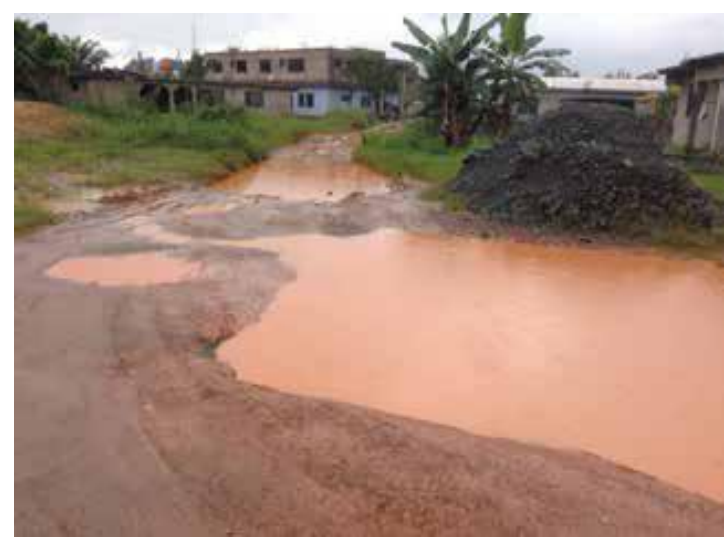

Source; Field Survey, June 2016

Figure 4. Development in the Kawere Basin in Tarkwa

Residents however indicated that, they spent huge sums of money to fill up the waterlogged places (see Figures 3and 4) as well as the foundation of the buildings. A resident remarked in an interview that "the amount of money I spent on the filling and building of the foundation alone can build two of the houses built in the waterlogged area". Others have attempted to drain the water through the laying of underground pipes. All these efforts, according to residents, are expensive and also a major source of conflicts among residents. It was revealed that when a resident fills the plot and raises the ground or drains the 
water on the land, it flows unto neighbouring plots which are not filled to the same level. Such plots get flooded and pools of water are found all over the area. Residents in the area interviewed also indicated that they had bought the land and showed evidence of plot allocation.

Planning authorities find it difficult to regulate such developments because of the land tenure systems in the study communities, where lands are owned largely by traditional authorities. They therefore indirectly determine who can own land and the use of such purchased or acquired lands. Though sections 117- 119 of the Land Use and Spatial Development Act 2016, Act 925 stresses on the importance of obtaining permits before physical development and giving the sanctions against offenders, planning authorities are unable to enforce such requirements because of the land ownership systems in place.

It was also observed that some of the residents whose plots are on the banks of the Kawere River have diverted the river at various points with the help of excavators. The physical planning department and the Municipal Assembly denied knowledge of such deeds but residents affirmed it and heaps of sand along the bank as well as the old course and the new course of the river were evidence of such happenings. This is clearly a disregard for the planning arrangements for such an area. These activities are neither safe nor sustainable. Planning responses to such development as indicated in the Planning Standards for Riparian Buffer Zones by the Ministry of Environment, Science and Technology and Town and Country Planning Development (2011) indicates that the desired minimum buffer width should be able to sustain stream protection and buffer functions over the long term, and potential future threats (like climate change), which may tend to impact negatively on runoff regime and the integrity of stream-side vegetation (see Table 1). Despite these restrictions, developers violated and built close to the Kawere basin because the lands were bought from the traditional authorities. The foregoing implies that there is weak or no enforcement of planning laws in land use in wetlands/water ways with no effective collaboration between traditional authorities and planning authorities the Municipality.

Table 1. Recommendations for Riparian Buffer Zones

\begin{tabular}{|c|c|}
\hline Zone & Requirement \\
\hline $\begin{array}{l}\text { Municipal reservoir shoreline } \\
\text { protective Buffer } \\
\text { Major perennial rivers/streams }\end{array}$ & $\begin{array}{l}60 \text { to } 90 \text { meters (e.g weija dam, } \\
\text { Lake Bosomtwe) } \\
10 \text { to } 60 \text { meters (e.g Volta, } \\
\text { Tano, Offin) }\end{array}$ \\
\hline Minor Perennial streams & 10 to 15 meters \\
\hline Important intermittent streams & 10 to 20 meters \\
\hline Streams within forest reserves & 10 to 50 meters \\
\hline
\end{tabular}

Source: Ministry of Environment, Science and Technology and Town and Country Planning Development (2011)
Tarkwa Nsuaem Municipality which lies within the South-Western Equatorial climatic zone experiences double maximum rainfall starting from March to September with a mean annual rainfall of $1,500 \mathrm{~mm}$. (GSS, 2014). The wet season is therefore longer than the period for the dry season. These areas which are in flood prone areas get flooded during such periods affecting most of the houses. This renders residents in this area vulnerable for most part of the year. Figure 5 shows the flood prone areas.

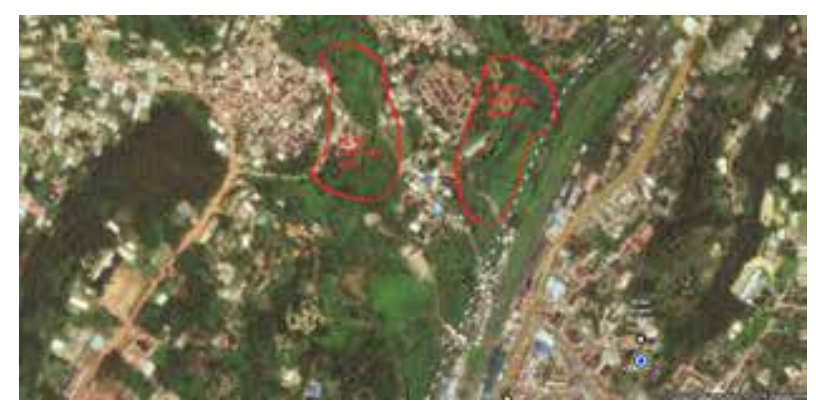

Source: Physical Planning Department TNMA, (2012)

Figure 5. Flood Prone areas in Tarkwa

A check on the base map of the area which is part of the Cynide- Kwabedu scheme shows that even though some portions of the areas have been demarcated for residential land use, areas close to the Kawere River were left as open spaces. These places have been developed and are built up. A major defect identified on the base map of the area is the fact that the map has no date. The head of the Physical Planning Department identified this as a major challenge with most of the existing base maps of the communities within the Municipality. Besides that, there are no base maps for some of the communities which make it difficult to prepare new or amended schemes and also monitor land uses of such areas. This situation therefore makes it difficult for the Municipal Spatial Planning Committee to enforce zoning schemes pursuant to structure plan as stipulated in section 84 of the Land use and Spatial Planning Act,2016 Act 925. Meanwhile land use planning in mining communities are meant to ensure that activities are organized and developed in physical spaces with due consideration for the protection of the public interest which include health, safety, convenience, efficiency, energy conservation, environmental quality, social equity, social choice and amenity" (Nnah et al, 2007). Land use planning is also an important component of urban management, where the sustainability of areas is influenced directly by land use controls, which promotes the efficient use of urban lands (Owei et al., 2009). The physical planning department is also under resourced in terms of equipment and personnel. Personnel interviewed at the Physical Planning unit indicated that they need two additional Physical planners to enhance their work in the Municipality. Response by city authorities to these land use challenges have been ineffective, slow and sometimes they do not 
enforce the regulations in the face of these challenges.

\subsection{Competing Demand for Land between Mining and Housing Development}

It was observed that gold extraction and processing takes place in many suburbs of Tarkwa such as; Cynide, the Kawere basin, Tamso, Abonteakon and Nsuta communities. Gold refinery is done near the Municipal Assembly and in spite of complaints by residents and owners of businesses around the area, not much has been done about the situation and this has been attributed to the lack of political will to enforce the laws. The institutions in charge of law enforcement such as; the Environmental Protection Agency, Minerals Commission and the Municipal Assembly appear to have little control over the situation.

These activities take place in residential areas as shown in Figure 6. and expose residents in these communities to a lot of problems such as acute mercury poisoning, silicosis, neurological and kidney damage, cardiovascular and respiratory dysfunctions (Hinton et al, 2003; Blacksmith Institute, 2011). As exemplified by Hardin's theory of "the Tragedy of the Commons" in 1968, illegal miners obtained the ore from an environment treated as common-pool resource for their individual economic satisfaction (Ghatak, 2005; Hardin, 1968 in Agyeman et al., 2012). The ramifications of the activities of these illegal miners who treat the mineral bearing land as common-property are however borne by the entire society. There is also intense competition for land between mining activities and housing development in the study areas. Mining activities have resulted in mining-induced displacement and resettlement in some areas, originally zoned for residential purposes. Through mining activities, hills have been graded down, vegetation covers of soils have been removed and deep pits have been created. These however serve as raw materials (soils) for developers in the construction industry in wetlands as is the case in the Kawere Basin.

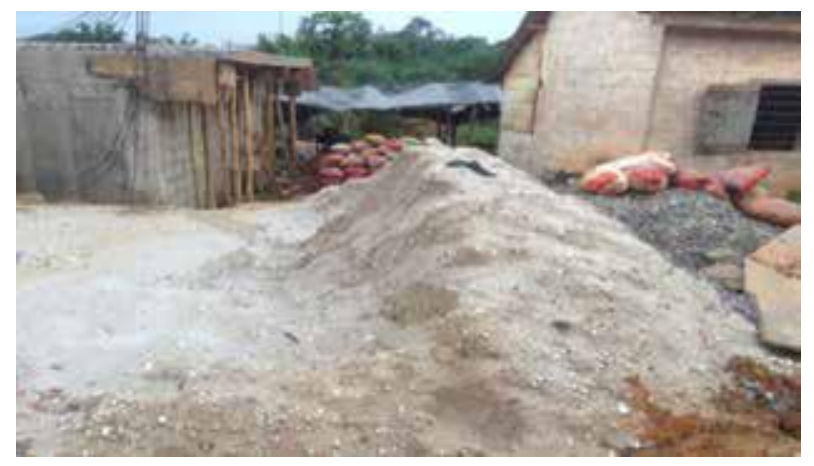

Source: Field Survey, June, 2016

Figure 6. Competing demand for land in Tarkwa.

Under the Land Sector, the Mining and Minerals policy aims at improving the delivery of land registration and other land-related services to the general public by establishing a Client Service Access Unit to serve as a front office for the Lands Commission and to provide a platform for a 'one-stop-shop' land service delivery. This if implemented and effectively enforced would serve as a key input to addressing the land use and management challenges that often come up as a result of arrangements that exist to acquire and develop lands in the Municipality. Another area of destruction of the natural environment is the creation of numerous uncovered pits in mining communities in the municipality. There are many uncovered pits dotted all over the study communities. Some of these pits are partially covered by vegetation. This poses danger to the environment and human health.

From all the issues discussed above, it is obvious that poor or weak planning responses to land use challenges and management in mining communities is likely to affect Ghana's efforts to achieve SDG11.6 by 2030 which urges countries to reduce the adverse per capita environmental impact of cities, including paying special attention to air quality, municipal and other waste management. Addressing this is therefore a prerequisite for the attainment of SDG 11.3 which aims at enhancing inclusive and sustainable urbanization and capacities for participatory, integrated and sustainable human settlement planning and management in all countries by 2030 .

\section{Conclusions}

The study was aimed at examining the planning responses to land use challenges and management practices in mining communities in Ghana, taking the Tarkwa-Nsuaem Municipality as a case study. Mining activities have had both positive outcomes in terms of its contribution to employment creation and contribution to GDP. The negative impact associated with the sector is however dire which has resulted in the destruction of vegetation, creation of mine pits, threats to human health through pollution of water bodies, air and the environment, among others. The mining activities of the Municipality have further resulted in increasing population within the communities without corresponding infrastructure and related service provisions. Due to the intense nature of mining activities and population, there have been intense competition over available lands which have resulted in congestions, changing land uses which are outside formal planning schemes, encroachments, and some developers, building in water ways and wetlands. Policy and planning responses have however been non-existent in terms of enforcement; inadequate and slow to addressing the land use and management challenges that are presented by mining activities in such communities.

Based on findings, the study makes the following recommendations: The study revealed that there were ineffective responses to many instances of non-conformity to planning laws and standards in the study areas such as 
encroachment on state lands and development outside the planning schemes as a result of the attraction of large numbers of people to the study areas by mining activities. Instead of enforcing planning laws and standards as stipulated in their functions in Section 38 of the Land Use and Spatial Planning Act, 2016 (Act 925) the Municipal Assembly rather chose to issue disclaimers and refusal of permits which did not address the challenges associated with non-conformity to planning laws and standards. To address this, it is recommended that the Municipal Assembly, through Municipal Spatial Planning Committee take decisive measures to enforce the laws and also collaborate with the information desk of the Municipal Assembly to educate residents on the Land Use and Spatial Planning Act, 2016 (Act and Local Governance Act, 2016 (936). It is believed that the enforcement of planning laws and the education of the residents on the planning laws and implications as well as sanctions for non-conformity will enhance the promotion of sustainable land use practices and management for socio economic development in the Municipality.

The study also calls for strict enforcement of existing laws and the enactment of new laws where blueprints for all uses of land within the local areas should be sought for and approved. There should also be the enactment and enforcement of bye-laws to manage the challenges of the CBD as a result of these phenomena. The laws should guide planning authorities to set parameters for future growth of the Municipal so as to effectively maximize the provision of necessary infrastructure and close the gap between local planning schemes and spatial outcomes taking the needs of all stakeholders into consideration.

The study also revealed that some of the planning responses to land use challenges and management took place without adherence to planning standards. For instance, parking facilities were provided without the required Transport Impact Assessment which resulted in the persistence of the problem of traffic congestion and conflicting views on the effectiveness of the responses to solving the problem of congestion at the CBD. It is recommended that the planning authorities in the municipality conduct a TIA to ensure a more effective way of addressing traffic congestion in the CBD. The study also revealed that earlier attempts to reduce traffic congestion by relocating the North bound vehicles to New Atuabo failed due to limited stakeholder consultation and the provision of appropriate facilities. It is recommended that the Spatial Planning Committee conducts effective stakeholder consultations and provide alternatives that are equal to or better than what the affected people are used to before the relocation to ensure sustainable and effective law enforcement.

As indicated earlier, traditional authorities own a large proportion ( 75 percent) of the land in the municipality and hence control a large proportion of land. It was revealed that there is little or no collaboration between planning authorities in the Municipality in relation to land market arrangements regarding who determines the use of such lands. Traditional authorities are often very powerful in the land market and as such determine the use of land within their areas of jurisdiction and this has resulted in developments outside approved planning areas. This situation makes it difficult to enforce strict adherence to planning standards in the study areas. It is therefore recommended that an effective collaboration between the traditional leaders and planning authorities should be promoted to clearly define the mandate of each stakeholder within the urban land market for effective enforcement of planning laws.

The study also calls for strict enforcement of existing laws and also the enactment of new laws where blueprints for all uses of land within the local areas should be sought for and approved. Thus, the requisite facilities should commensurate local standards. There should also be the enactment and enforcement of bye-laws to manage the challenges of the CBD. The laws should guide planning authorities to set parameters for future growth of the study urban communities so as to effectively maximize the provision of necessary infrastructure, taking the needs of all stakeholders into consideration through broad stakeholder consultation, education and effective communication.

The Physical Planning Department of the Municipality was found to be under resourced in terms of personnel and equipment and this has affected their response to land use challenges. It is therefore proposed that the Municipal Assembly resources the Physical planning department with modern equipment, such as a GIS Laboratory with soft wares (ARC GIS and MAP MAKER) to enable the preparation of base maps that have dates and to carry out digitization of maps of the area. This will aid in subsequent updating of the maps which will make them effective and efficient at the execution of their duties and also facilitate holistic and timely development of plans for their clients in the municipality. It is also recommended that at least two more Physical planners are posted to the Municipal Assembly and technical staff trained to use modern equipment to enhance effective enforcement of planning laws in the Municipality.

The study also revealed that planning authorities sometimes lack the political will to enforce the planning laws as in the case of the gold processing activities near the Municipal Assembly. Again, they are also not firm in enforcing the planning laws but rather collect tolls from unapproved land uses thus apparently endorsing nonconformity to planning laws and standards. It is recommended that the planning authorities take decisive measures to address land use challenges devoid of political interferences and the quest to generate revenue out of illegal land use. Strict enforcement of the minerals and 
mining laws will help minimize the adverse effects of mining in the study urban communities.

\section{REFERENCES}

[1] Adarkwa, K.K. (ed.) (2014) Human Settlements and Service Delivery in Ghana. Kumasi. Kumasi, University Printing Press (UPK) Kwame Nkrumah University of Science and Technology.

[2] Agbesinyale, P. K. (2003): Ghana's Gold Rush and Regional Development; The Case of Wassa West District. Spring Research Series No. 44, Dortmund.

[3] Agyeman, K. O., Amponsah, O., Braimah, I. and Lurumuah, S. (2012). -Commercial Charcoal Production and Sustainable Community Development of the Upper West Region, Ghana. Journal of Sustainable Development, 5(4):149-164.

[4] Akabzaa, T. (2000) Boom and Dislocation: Environmental Impacts of Mining in the Wassa West District of Ghana. Accra, Ghana Third World Network

[5] Akabzaa, T. and Darimani, A. (2001). Impact of mining sector investment in Ghana: A study of the Tarkwa mining region - A Draft Report, available www.saprin.org/ghana/ research/gha_mining.pdf.

[6] Amegbey, N.A., Dankwa, J.B.K., Al-Hassan, S. (1997), Small-scale mining in Ghana- techniques and environmental considerations. International Journal of Surface Mining, Reclamation and Environment 11, 135138 .

[7] Amoako, C., Cobbinah, P.B., and Niminga-Beka R. (2014). Urban Infrastructure Design and Pedestrian Safety in the Kumasi Central Business District, Ghana. Journal of Transportation Safety \& Security 6:235-256

[8] Antwi-Boasiako, A. (2003): Proliferation of Surface Mining in Ghana: A Blessing to the Poor in Mining Areas? A case study of Tarkwa Mining Area (MSc. Thesis-Lund, Sweden)

[9] Arko-Adjei, A. (2005). Titling Customary Lands: Emerging Challenges Facing the Land. TS02D - Customary and Group Land Rights, 5739

[10] Aryee, N.N.A, Ntibrey, B. K., Atokui, E. (2003). Trends in the small-scale mining of precious minerals in Ghana: a perspective on its environmental impact, Journal of Cleaner Production, Vol. 11, No. 1, pp. 131-140

[11] Aryeetey, E., Al- Hassan, R.M., Asuming-Brempong, S. and Twerefou, D.K. (2007). The Organization of Land Markets and Production in Ghana. ISSER, Accra, Technical Publication, No. 73, pp. 8-21.

[12] Avirgan, T., L. Bivens and S. Gammage (eds.) (2005), "Good Jobs, Bad Jobs, No Jobs, Labour Markets and Informal Work in Egypt, El Salvador, India, Russia, and South Africa", Economic Policy Institute, Washington, D.C.

[13] Barlow, R (1978) Land Resources Economy, Second Edition, Prentice Hall

[14] Blacksmith Institute (2011). Artisanal Gold Mining. Blacksmith Institute. New York
[15] Boamah, N.A., (2013). Land use controls and residential land values in the Offinso South municipality, Ghana. Land Use Policy33, 111-11

[16] Briassoulis, H, (1999). Analysis of Land Use Change: Theoretical and Modelling Approaches University of the Aegean. Department of Geography, Lesvos, Greece

[17] Briassoulis, H. (2000). Analysis of Land Use Change: Theoretical and Modelling Approaches. The Web Book of Regional Science. (R. W. Jackson, Ed.) Virginia, USA: Regional Research

[18] Buxton, A., 2013. Responding to the challenge of artisanal and small-scale mining. How can knowledge networks help? IIED, London

[19] Chapin, F. S. and Kaiser, E. J. (1979) Urban Land Use Planning, University of Illinois, St. Champaign.

[20] Clarke, G. (1994). Reappraisal of the urban planning process as an instrument for sustainable urban development and management. In A.C. Mosha, A reappraisal of the urban planning process (pp. 13\}28). Nairobi: UNCHS

[21] Compliance with urban development and planning regulations in Ibadan, Nigeria. Available from: https://www.researchgate.net/publication/222241379 Compliance_with_urban_development_and_planning regulations_in_Ibadan_Nigeria [accessed Mar 3, 2017].

[22] Dorner, U., Franken G., Liedtke M and Sievers, H., (2012). Artisanal and Small-Scale Mining (ASM). POLINARES working paper n. 19, March 2012

[23] Food and Agriculture Organization (2009) The State of Food and Agriculture, Food and Agriculture Organization (FAO), Rome.

[24] Food and Agriculture Organization (FAO) (1995). Planning for Sustainable Use of Land Resources. FAO Land and Water Bulletin 2. Rome, Italy.

[25] Gareth, J, (1991). The Commercialisation of the Land Market? Land ownership patterns in the Mexican city of Puebla. Third World Planning Review, vol. 13, no. 2, pp. $129-153$

[26] Getis A, Getis J \& Fellmann J. D. (2006). Introduction to Geography. 10th ed. New York: McGraw Hill. p 424.

[27] Getis, A., Getis J. and Fellman J.D. (2004), Introduction to Geography. 9th Edition. New York, USA McGraw Hill Companies, Inc.

[28] Ghana Statistical Service (GSS) (2014). 2010 Population and Housing Census: District Analytical Report, Tarkwa Nsuaem Municipality, Accra; Ghana Statistical Service (GSS)

[29] Gondo T (2009) Urban land and Informality: An evaluation of institutional response options to land Informalisation in Ethiopian cities

[30] Hilson, G and Potter, C. (2005). Structural Adjustment and Subsistence Industry: Artisanal Gold Mining in Ghana, Development and Change, Vol. 36, NO. 1, pp. 103-131.

[31] Hilson, G., (2002). Harvesting mineral riches: 1000 years of gold mining in Ghana, Resources Policy 28 (1-2), 13-26. 
[32] Hinton J. J, Veiga M. M, Veiga A. T. C. (2003) Clean artisanal gold mining: a utopian approach? Journal of Cleaner Production 11(2): 99-115.

[33] Hruschka, F. and Echavarria, C., (2011). Rock-Solid Changes: For Responsible Artisanal Mining, ARM Series on Responsible ASM No. 3, ARM, Medellín, Colombia. Available at www.communitymining.org/ attachments/059_RSC_FINAL_web_low. pdf.

[34] Ilesanmi, A. O. (2010). Urban sustainability in the context of Lagos mega-city. Journal of Geography and Regional Planning, 3(10), 240-252.

[35] Kasanga, K.R. (2008). Land Policy and Land Management from the Traditional Perspective in Ghana, a Paper Presented at the University of Leeds, UK.

[36] Kivell P. (1993). Land and the City; Patterns and processes of urban change, Routledge, London \& New York.

[37] Koroso, N.H (2011), Assessment of Urban Land Market from Good Governance Perspective, University of Twente, Enschede, the Netherlands

[38] Land Administration Project (2007). Objectives of the Land Administration Project, Ghana. Retrieve from http://www.ghanalap.gov. gh. in Peri urban Ghana. Journal of Legal Pluralism and Unofficial Law, 55

[39] Lekwot, V.E., Samuel, I.O., Ifeanyi., E. and Olisaemeka, O. (2013) Evaluating the potential of rainwater harvesting as a supplementary source of water supply in the Kanai (Mali) and the district of Zangon-Kataf local government area of Kaduna State, Nigeria. Global Advanced Research Journal Environmental Science and Toxicology 1 (3), pp. 38-45.

[40] Mabogunje, A. L. (2002) "Re - constructing the Nigerian City: The New Policy on Urban Development and Housing". A keynote address in Amole, D. et al. The City in Nigeria: Perspective, Issues, Challenges, Strategies. Proceedings of a National Conference. Obafemi Awolowo University Ile Ife, Nigeria, pp $1-9$

[41] Mandkerlker and Payne, G. (2001). Urban land tenure policy options, Titles or Rights. Habitat International,25(3), 415-429

[42] McDonagh J. (2007). "Theories of Urban Land Use and Their Application to the Christchurch Property Market" Land Economics subject reader, Lincoln University 2007.

[43] Miller, G. T. (1996). Living in the Environment: Principles, Connections and Solutions, 9th ed. California: Wadsworth, pp $12,265,453,667$.

[44] Ministry of Environment Science and Technology and Town and Country Department (2011), Zoning Guidelines and Planning Standards. Ministries, Accra, Ghana.

[45] Nnah, W. W.; O. B. Owei and M. Ikpoki (2007). "Development Control and the Public Interest in Obio/Akpor Local Government Area of Rivers State, Nigeria". In: Journal of the Nigerian Institute of Town Planners. Vol. XX No. 1. December.

[46] Nwaka, G. I. (2005) “The Urban Informal Sector in Nigeria: Towards Economic Development, Environmental Health and Social Harmony. Mimeo. Prague Institute for Global Urban Development, May 2005.
[47] Ocansey, I.T. (2013). Mining Impacts On Agricultural Lands and Food Security: - Case study of towns in and around Kyebi in the Eastern Region of Ghana. Bachelor's thesis International Business International Business Management. Accessed athttps://www.theseus.fi/bitstream /handle/10024/53720/Ocansey_Ignitious.pdf?sequence

[48] Ogungbemi, O. A. (2012). Factors influencing change of use and its attendant problems: case study of Yaya Abatan, Ogba, Lagos State, Journal of Emerging Trends in Economics and Management Sciences, 3(6), 901-906.

[49] Ojigi, M. L. (2012). An Evaluation of the Efficiency of the Land Use Act 1978 of the Federal Republic of Nigeria and its Implications in Minna and Environs (TS01E - Pro Poor Land Management, 5577). International Federation of Surveyors (FIG) Working Week: Knowing to manage the territory, protect the environment, and evaluate the cultural heritage. Rome Italy

[50] Olima, W. H. A. (1993). The Land Use Planning in Provincial Towns of Kenya: A Case Study of Kisumu and Eldore towns. Project Verlag, Dortmund, Germany.

[51] Opoku-Ware, K. and Kutor, N (2015). Mining Our Lives Out: A Food Security Approach to Mining Operation in Asutifi District of Ghana, International Journal of Development Research, Vol. 5, No.1, pp. 3037-3045.

[52] Owei, O.B., Obinna, V.C. and Ede, P.N. (2009). The Challenges of Sustainable Land Use Planning in Nigerian Cities: The Case of Port Harcourt. 46th ISOCARP Congress 2010. Accessed at http://www.isocarp.net/data/ case studies/1740.pdf on January 13, 2017

[53] Oyesiku, O. K. (2009) "City Live ability: Implications and Challenges". Lead Paper presented at the Commonwealth Association of Planners, West Africa Workshop. Lagos. Nov. 2009.

[54] Raharjo, Y.J. (2005). Physical Structure and Pattern of Land Use Changes from Residential into Commercial: Analyses of Mampang Prapatan, Jakarta, Indonesia. UMD1-21 Lund, September 2005

[55] Republic of Ghana (2016). Local Governance Act 2016 (Act 936). Accra, Ghana Publishing Company Limited, Assembly Press.

[56] Republic of Ghana (2016). Local Governance Land Use and Spatial Planning Act, 2016. (Act 925). Accra, Ghana Publishing Company Limited, Assembly Press.

[57] Tsikata, F.S (1997). The Vicissitudes of Mineral Policy in Ghana. Resources Policy Vol. 23 No.1/2 pp. 9 - 14

[58] Turner, R. Jay, Blair Wheaton, and Donald A. Lloyd (1995). "The Epidemiology of Social Stress." American Sociological Review 60:104-25.

[59] Ubink, J. M. (2008). Struggles for land in Peri-urban Kumasi and their effect on popular perceptions of chiefs and chieftaincy. In J. M. Ubink \& K. S. Amanor (Eds.), Contesting

[60] United Nations Economic Commission for Africa, (2004). Land Tenure Systems and their Impacts on Food Security and Sustainable Development in Africa.

[61] Wehrmann, B. (2008). Land Conflicts: A practical guide to dealing with land disputes. Deutsche Gesellschaft 
für,Technische Zusammenarbeit (GTZ) GmbH. Eschborn, Germany

[62] Yaguang, S. (2011). Development and Characteristics of central business district under the philosophy of health. Procedia Engineering, 21, 258-266 